\title{
MODEL SPASIAL OTOREGRESIF POISSON UNTUK MENDETEKSI FAKTOR-FAKTOR YANG BERPENGARUH TERHADAP JUMLAH PENDERITA HIV/AIDS DI JAKARTA TIMUR
}

\author{
Siti Rohmah Rohimah ${ }^{1, \text { a) }}$, Ariq Muammar Riyantobi ${ }^{1, b)}$ \\ ${ }^{1}$ Program Studi Statistika Fakultas Matematika dan Ilmu Pengetahuan Alam Universitas Negeri Jakarta

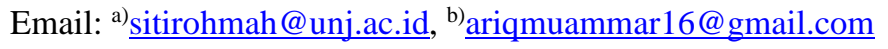

\begin{abstract}
This study aims to determine the factors that affect the spatial or non-spatial to the number of people with HIV / AIDS in East Jakarta. The method used in estimating the parameters uses the maximum likelihood estimation method. Factors affecting the number of people with HIV / AIDS in East Jakarta are spatial and non-spatial factors. The spatial factor that affects a particular location is the adjacent location. Based on the SAR Poisson models obtained significant spatial correlation of $\rho=-0.47$. This means that adjacent locations have different values and tend to spread.
\end{abstract}

Keywords: HIV/AIDS, Poisson Regression, Spatial Autoregressive Poisson

\begin{abstract}
Abstrak
Penelitian ini bertujuan untuk menentukan faktor-faktor yang berpengaruh secara spasial maupun nonspasial terhadap jumlah penderita penyakit HIV/AIDS di Jakarta Timur. Metode yang digunakan dalam pendugaan parameternya menggunakan metode pendugaan maksimum likelihood. Faktor-faktor yang mempengaruhi jumlah penderita HIV/AIDS di Jakarta Timur adalah faktor spasial dan nonspasial. Faktor spasialnya yang memengaruhi untuk lokasi tertentu adalah lokasi pada tetangganya. Berdasarkan model SAR Poisson diperoleh korelasi spasial yang signifikan sebesar $\rho=-0,47$. Hal ini berarti bahwa lokasi-lokasi yang berdekatan mempunyai nilai yang berbeda dan cenderung menyebar.
\end{abstract}

Kata-kata kunci: HIV/AIDS, Regresi Poisson, Spasial Otoregresif Poisson

\section{PENDAHULUAN}

\section{Latar Belakang}

Pemerintah Indonesia sedang menggalakan peningkatan kesehatan bagi masyarakatnya. Hal ini penting karena kesehatan memiliki peranan yang sangat penting dalam investasi sumber daya 
manusia. Oleh karena itu, pemerintah giat melakukan perbaikan di bidang kesehatan secara terus menerus dan berkesinambungan.

Perkembangan epidemi HIV/AIDS di dunia telah menjadi masalah global termasuk di Indonesia. Laporan kasus baru terus meningkat setiap tahunnya, namun sulit untuk mengetahui jumlah infeksi HIV yang sebenarnya ada. Untuk memahami epidemi yang terjadi di Indonesia, maka perlu dilakukan perhitungan estimasi jumlah populasi kunci terdampak HIV/AIDS. Estimasi jumlah populasi kunci dan orang dengan HIV/AIDS (ODHA) telah dilakukan oleh beberapa pihak. Hal tersebut dilakukan untuk memahami potensi epidemi dalam suatu area, memperkirakan beban dari suatu penyakit, dan menyusun prioritas yang sesuai dalam merespon epidemi HIV/AIDS.

Salah satu pihak yang melakukan proyeksi HIV/AIDS tahun 2011-2016 di Indonesia adalah kementerian kesehatan. Hal ini bertujuan untuk memberikan gambaran yang lebih jelas tentang situasi epidemi HIV saat ini dan perkiraan ke depan sehingga dapat digunakan oleh berbagai pihak dalam merencanakan program penanggulangan HIV dan AIDS di Indonesia yang lebih baik dan terarah. Selain itu, estimasi dan proyeksi ini juga diharapkan dapat digunakan sebagai dasar dalam melakukan evaluasi pelaksanaan berbagai program penanggulangan HIV dan AIDS yang sedang berjalan serta advokasi untuk meningkatkan komitmen berbagai pihak yang terlibat secara langsung maupun tidak langsung. Adapun tujuan penelitian ini diharapkan berguna untuk melakukan analisis kebijakan dalam penanggulangan HIV dan AIDS, menentukan prioritas program dan memperkirakan sumber daya untuk pelaksanaan berbagai program khususnya di Jakarta Timur.

Penyakit HIV dan AIDS adalah new emerging diseases serta menjadi pandemi di beberapa kawasan dalam beberapa waktu terakhir ini. Salah satu jenis penyakit yang perlu diperhatikan di DKI Jakarta adalah mengenai HIV dan AIDS. Jumlah kasus HIV meningkat terus dari tahun 2005 sampai dengan 2017. DKI Jakarta merupakan provinsi nomor empat dengan pengidap AIDS terbanyak, setelah Papua, Papua Barat, dan Jawa Timur. Tercatat dari data Komisi Penanggulangan AIDS Provinsi (KPAP) jumlah pengidap AIDS di Ibukota mencapai 42 ribu jiwa pada akhir 2016. Jumlah kumulatif kasusnya dilaporkan sampai dengan Desember 2017 sebanyak 280.623. Jumlah infeksi HIV tertinggi yaitu DKI Jakarta yaitu sejumlah 51.981 kasus (Ditjen P2P, 2017). Selain itu, data jumlah kasus HIV dan jumlah kasus AIDS berupa count maka pemodelan menggunakan regresi poisson.

Penelitian ini akan memodelkan faktor-faktor yang mempengaruhi jumlah HIV dan AIDS secara spasial maupun nonspasial di Jakarta Timur menggunakan SAR Poisson. Epidemi HIV/AIDS terjadi hampir di seluruh provinsi di Indonesia. Hal ini disertai kesenjangan yang cukup besar pada berbagai karakteristik, geografis, kapasitas sistem kesehatan, dan sumber yang tersedia. Penelitian ini diharapkan dapat membantu pemerintah untuk menanggulangi HIV/AIDS agar pencegahan dampak buruk pada pengguna narkoba suntik serta menyediakan informasi pencegahan untuk seluruh golongan remaja dan dewasa muda (BPPK Kemenkes, 2010).

\section{Tujuan Penelitian}

Tujuan penelitian ini adalah untuk mengetahui aktor-faktor yang mempengaruhi jumlah penderita HIV/AIDS di Jakarta Timur.

\section{TINJAUAN PUSTAKA}

\section{Acquired Immune Deficiency Syndrome (AIDS)}

Acquired Immune Deficiency Syndrome (AIDS) disebabkan oleh Human Immunodeficiency Virus (HIV) yang menyebabkan melemahnya sistem kekebalan tubuh seseorang, membuatnya lebih rentan terhadap berbagai penyakit, sulit sembuh dari berbagai penyakit infeksi oportunistik, dan bisa menyebabkan kematian. Epidemi HIV/AIDS terjadi hampir di seluruh propinsi di Indonesia. Hal ini disertai kesenjangan yang cukup besar pada berbagai karakteristik, geografis, kapasitas sistem kesehatan, dan sumber yang tersedia. Banyak upaya yang dilakukan pemerintah untuk menanggulangi HIV/AIDS yang dikenal sebagai Rencana Aksi Nasional 2007-2010 diantaranya yaitu meningkatkan pencapaian 80 persen kegiatan pencegahan dampak buruk pada pengguna narkoba suntik, 
mempromosikan penggunaan 100 persen di wilayah hotspot untuk menjangkau 80 persen pekerja seks komersial, dan menyediakan informasi pencegahan untuk seluruh golongan remaja dan dewasa muda (BPPK Kemenkes, 2010).

Sejak pertama kali ditemukan tahun 1987 sampai dengan Maret 2013, HIV/AIDS tersebar di 345 (69.4\%) dari 497 kabupaten/kota di seluruh provinsi di Indonesia. Berdasarkan laporan situasi perkembangan HIV/AIDS di Indonesia sampai dengan tahun 2013, jumlah infeksi HIV tertinggi yaitu DKI Jakarta (23792), Jawa Timur (13599), Papua (10881), Jawa Barat (7621), dan Bali (6819). Cara penularan HIV pada umumnya melalui hubungan heteroseksual, penggunaan jarum suntik bersama pada pengguna narkoba suntik, penularan dari ibu ke bayi selama periode kehamilan, kelahiran dan menyusui, transfusi darah yang tidak aman, dan praktek tatoo.

Segala sesuatu saling berhubungan satu dengan yang lainnya, tetapi sesuatu yang dekat lebih mempunyai pengaruh daripada sesuatu yang jauh (Tobler dalam Anselin, 1988). Adanya efek spasial merupakan hal yang lazim terjadi antara satu wilayah dengan wilayah yang lain. Model yang dapat menjelaskan hubungan antara suatu wilayah dengan wilayah sekitarnya adalah model spasial. Penderita HIV/AIDS dari satu wilayah diduga dapat dipengaruhi oleh wilayah sekitarnya dan menyebar Poisson. Oleh karena itu, dalam penelitian ini menggunakan model Spatial Autoregressive Poisson (SAR Poisson) untuk melihat faktor-faktor yang berpengaruh terhadap jumlah penderita HIV/AIDS di Jakarta Timur.

Segala sesuatu saling berhubungan satu dengan yang lainnya, tetapi sesuatu yang dekat lebih mempunyai pengaruh daripada sesuatu yang jauh (Tobler dalam Anselin, 1988). Adanya efek spasial merupakan hal yang lazim terjadi antara satu wilayah dengan wilayah yang lain. Model yang dapat menjelaskan hubungan antara suatu wilayah dengan wilayah sekitarnya adalah model spasial. Penderita HIV/AIDS dari satu wilayah diduga dapat dipengaruhi oleh wilayah sekitarnya dan menyebar Poisson. Banyak faktor yang diduga mempengaruhi jumlah penderita HIV/AIDS antara lain jumlah kepadatan penduduk, banyaknya pusat kesehatan masyarakat, dan banyaknya tumpukan sampah.

\section{Model Regresi Poisson}

Regresi Poisson merupakan suatu fungsi regresi dengan peubah respon (Y) yang mempunyai sebaran peluang Poisson, misalkan peubah cacah Y menyatakan banyaknya kejadian yang terjadi dalam suatu periode waktu atau wilayah tertentu. Sebaran Poisson ditentukan oleh fungsi peluang (Fleiss et al. 2003).

$$
\mathrm{P}(\mathrm{Y}=\mathrm{y} \| \mu)=\frac{\mathrm{e}^{-\mu_{\mu} y}}{\mathrm{y} !} \text {, untuk } \mathrm{y}=0,1,2, \ldots
$$

Misalkan $\mathrm{Y}_{1}, \ldots, \mathrm{Y}_{\mathrm{n}}$ merupakan contoh acak dari sebaran peluang Poisson dengan rata-rata $\mu_{\mathrm{i}}$. Fungsi massa peluang $Y_{i}$ dinyatakan sebagai berikut.

$$
\mathrm{f}\left(\mathrm{y}_{\mathrm{i}} \mid \mu_{\mathrm{i}}\right)=\frac{\mu_{\mathrm{i}}^{\mathrm{y}_{\mathrm{i}}}-\mathrm{H}_{\mathrm{i}}}{\mathrm{y}_{\mathrm{i}}^{!}}
$$

Misalkan $\boldsymbol{\eta}=\mathbf{X}^{\prime} \boldsymbol{\beta}$ merupakan komponen sistematik yang merupakan fungsi linear dari peubah penjelas $X$ dan parameter $\boldsymbol{\beta}$ yang tidak diketahui. $\eta$ dihubungkan dengan $\mu$ melalui fungsi penghubung $\mathrm{h}(\mu)=\boldsymbol{\eta}$ dengan $\mathrm{h}(\mu)=\log \mu$. Sehingga model regresi Poisson berganda dapat dituliskan sebagai berikut.

$$
\log \mu_{\mathrm{i}}=\mathrm{x}_{\mathrm{i} 1} \beta_{1}+\ldots+\mathrm{x}_{\mathrm{ik}} \beta_{\mathrm{k}}+\varepsilon_{\mathrm{i}}
$$

dengan $\mathrm{x}_{\mathrm{ik}}$ merupakan peubah penjelas ke-k pada pengamatan ke-i dan $\mathrm{i}=1,2, \ldots, \mathrm{n}$ (Cameron dan Trivedi, 1998).

Faktor-faktor yang diduga mempengaruhi jumlah penderita HIV/AIDS adalah faktor spasial dan nonspasial. Faktor spasial yang mempengaruhi jumlah penderita HIV/AIDS di lokasi tersebut adalah jumlah penderita HIV/AIDS pada lokasi tetangganya. Sedangkan faktor nonspasial yang diduga mempengaruhi jumlah penderita HIV/AIDS yang digunakan antara lain: laju pertumbuhan penduduk 
$\left(\mathrm{X}_{1}\right)$, jumlah fasilitas kesehatan $\left(X_{2}\right)$, jumlah dokter dan bidan $\left(\mathrm{X}_{3}\right)$, jumlah petugas penyuluh $\mathrm{KB}$ $\left(\mathrm{X}_{4}\right)$, jumlah rumah tangga miskin $\left(\mathrm{X}_{5}\right)$, jumlah tempat ibadah $\left(\mathrm{X}_{6}\right)$, dan jumlah timbunan $\operatorname{sampah}\left(\mathrm{X}_{7}\right)$.

\section{Model SAR (Spatial Autoregressive Model)}

Matriks ketergantungan spasial adalah matriks yang menggambarkan hubungan antar daerah. Baris ke-i dari matriks pembobot menunjukkan hubungan pengamatan ke-i dengan semua pengamatan lainnya. Oleh karena itu matriks pembobot berukuran $(n \times n)$, dengan $n$ merupakan jumlah semua pengamatan. Matriks pembobot yang digunakan berdasarkan tetangga terdekat (Fotheringham dan Rogerson 2009), yang didefinisikan sebagai berikut:

$$
W_{\mathrm{ij}}=\left\{\begin{array}{l}
1, \text { jika } \mathrm{j} \text { merupakan tetangga terdekat } \mathrm{i} \\
0, \text { lainnya }
\end{array}\right.
$$

Baris pada matrik ketergantungan spasial menunjukkan hubungan spasial suatu daerah dengan daerah lain, sehingga jumlah nilai pada baris ke-i merupakan jumlah tetangga yang dimiliki oleh daerah i yang dinotasikan: $c_{\mathrm{i}}=\sum_{\mathrm{j}=1}^{\mathrm{n}} \mathrm{c}_{\mathrm{ij}}$ dengan $\mathrm{c}_{\mathrm{i}, \mathrm{i}}$ merupakan jumlah pembobot seluruh baris ke-i dan $\mathrm{c}_{\mathrm{ij}}$ nilai pembobot pada baris ke-i dan kolom ke-j. Sedangkan $\left(w_{\mathrm{ij}}^{*}\right)=\frac{\mathrm{c}_{\mathrm{ij}}}{\mathrm{c}_{\mathrm{i}}}$, nilai $w_{\mathrm{ij}}^{*}$ ini adalah elemen matriks yang sudah dinormalkan sehingga jumlah setiap baris sama dengan 1 .

Bentuk persamaan model SAR (Fotheringham dan Rogerson, 2009) dapat ditulis sebagai berikut:

$$
y_{\mathrm{i}}=\rho \sum_{\mathrm{j}=1}^{\mathrm{n}} w_{\mathrm{ij}}^{*} y_{\mathrm{j}}+\mathrm{x}_{\mathrm{i}} \boldsymbol{\beta}+\varepsilon_{\mathrm{i}}
$$

dengan $\rho$ merupakan koefisien spasial otoregresif, $w_{\text {iij }}^{*}$ merupakan matriks pembobot spasial yang sudah dibakukan pada daerah ke-i dan tetangga ke-j, serta $\varepsilon_{\mathrm{i}}$ galat acak yang bebas stokastik identik.

Jika model SAR ditulis dalam bentuk matriks sebagai berikut:

$$
\boldsymbol{y}=\rho W^{*} y+\mathbf{X} \beta+\varepsilon
$$

Bentuk reduksi SAR menjadi persamaan berikut:

$$
\boldsymbol{y}=\mathbf{A}^{-1} \mathbf{X} \boldsymbol{\beta}+\boldsymbol{\varepsilon}^{*}
$$

dengan $\mathbf{A}=\mathbf{I}-\rho \mathbf{W}^{*}, \mathbf{A}^{-1}$ merupakan matriks balikan $\mathbf{A}$ dan $\boldsymbol{\varepsilon}^{*}=\mathbf{A}^{-1} \boldsymbol{\varepsilon}$.

Penggunaan spasial pada model otoregresif untuk data cacah (Lambert et al. 2010) adalah:

$$
\mu_{\mathrm{i}}^{\mathrm{SAR}}=\exp \left[\boldsymbol{a}_{\mathrm{i}} \mathbf{X} \boldsymbol{\beta}\right]
$$

dengan $\boldsymbol{a}_{\mathfrak{i}}$ merupakan vektor baris pada daerah ke-i yang berukuran $(1 \times n)$. Pada model SAR Poisson, nilai harapan pada daerah atau lokasi ke-i merupakan fungsi dari daerah tetangganya atau lokasi ke-j. Selain itu model SAR Poisson juga digunakan untuk data pada peubah respon yang berbentuk cacahan (count data). Fungsi massa peluang dari model SAR Poisson adalah:

$$
\mathrm{f}\left(\mathrm{y}_{\mathrm{i}} \mid \mathbf{X}, \boldsymbol{W}^{*} ; \boldsymbol{\beta}, \boldsymbol{\rho}\right)=\frac{\left(\mu_{i}^{\mathrm{SAR}}\right)^{Y_{\mathrm{i}}} \exp \left(-\mu_{i}^{\mathrm{SAR}}\right)}{\mathrm{w}_{1}^{?}}
$$

dengan

$$
\mu_{i}^{\mathrm{SAR}}=\exp \left(\boldsymbol{\alpha}_{i} \mathbf{X} \boldsymbol{\beta}\right)
$$

Fungsi kemungkinannya adalah,

$$
\mathrm{L}\left(\boldsymbol{\beta}, \rho \mid \mathbf{X}, \boldsymbol{W}^{*} ; \mathbf{y}_{1}, \mathrm{y}_{2}, \ldots, \mathrm{y}_{\mathrm{n}}\right)=\prod_{\mathrm{i}=1}^{\mathrm{n}}\left\{\frac{\left(\mu_{i}^{\mathrm{SAR}}\right)^{\mathrm{y}_{\mathrm{i}}} \exp \left(-\mu_{i}^{\mathrm{SAR}}\right)}{\mathrm{y}_{1} !}\right\}
$$

Pendugaan parameter $\boldsymbol{\rho}$ dan $\boldsymbol{\beta}$ menggunakan metode kemungkinan maksimum. Fungsi massa peluang dari sebaran Poisson adalah: 


$$
\mathrm{f}\left(\mathrm{y}_{\mathrm{i}} \mid \mathbf{X}, \boldsymbol{W}^{*} ; \boldsymbol{\beta}, \rho\right)=\frac{\left(\mu_{\mathrm{i}}^{\mathrm{SAR}}\right)^{\mathrm{Yi}_{\mathrm{i}}} \exp \left(-\mu_{\mathrm{i}}^{\mathrm{SAR}}\right)}{\mathrm{w}_{1}^{\mathrm{l}} \mathrm{i}}
$$

dengan $\mu_{\mathrm{i}}^{\text {SAR }}=\exp \left(\boldsymbol{a}_{\mathrm{i}} \mathbf{X} \boldsymbol{\beta}\right)$, fungsi log kemungkinan maksimum adalah,

$$
\ln \mathrm{L}\left(\boldsymbol{\beta}, \rho \mid \mathbf{X}, \mathbf{W}^{*} ; \mathrm{y}_{1}, \mathrm{y}_{2^{\prime}}, \ldots, \mathrm{y}_{\mathrm{n}}\right)=\boldsymbol{y}^{\prime} \mathbf{A}^{-1} \mathbf{X} \boldsymbol{\beta}-\sum_{\mathrm{i}=1}^{\mathrm{n}} \exp \left(\left[\boldsymbol{a}_{\mathrm{i}} \mathbf{X} \boldsymbol{\beta}\right]\right)-\sum_{\mathrm{i}=1}^{\mathrm{n}} \ln \left(\mathrm{y}_{\mathrm{i}} \mathrm{D}\right)
$$

Pendugaan parameter $\rho$ dan $\boldsymbol{\beta}$ pada model SAR Poisson menggunakan iterasi dengan metode Newton-Raphson. Tahapan dari metode Newton-Raphson terdiri dari,

1. Menentukan $\widehat{\boldsymbol{\beta}}_{(0)}^{*}$, dengan $\boldsymbol{\beta}_{(0)}^{*}=\left[\rho_{0} \beta_{00} \beta_{10 \ldots} \beta_{k o}\right]$, iterasi pada saat $\mathrm{t}=0$.

2. Membentuk vektor gradien $g_{\mathrm{t}+1}^{\prime}=\left[\frac{\partial \mathrm{L}\left(\beta^{*}\right)}{\partial \mathrm{p}}, \frac{\partial \mathrm{L}\left(\beta^{*}\right)}{\partial \beta}\right]$, dengan $\mathrm{t}$ menyatakan nomor iterasi.

3. Membentuk matrks Hessian $\mathbf{H}$ :

$$
\mathbf{H}_{(\mathrm{k}+1) \mathrm{x}(\mathrm{k}+1)}=\left[\begin{array}{ccccc}
\frac{\partial^{2} \ln \mathrm{L}\left(\beta^{*}\right)}{\partial \rho^{2}} & \frac{\partial^{2} \ln \mathrm{L}\left(\beta^{*}\right)}{\partial \beta_{0} \partial \rho} & \ldots & \frac{\partial^{2} \ln \mathrm{L}\left(\beta^{*}\right)}{\partial \beta_{\mathrm{k}} \partial \rho} \\
& \frac{\partial^{2} \ln \mathrm{L}\left(\beta^{*}\right)}{\partial \beta_{0}^{2}} & \ldots & \frac{\partial^{2} \ln \mathrm{L}\left(\beta^{*}\right)}{\partial \beta_{0} \beta_{k}} \\
& \ddots & \vdots \\
& & & \frac{\partial^{2} \ln \mathrm{L}\left(\beta^{*}\right)}{\partial \beta_{k}^{2}}
\end{array}\right]
$$

4. Memasukkan nilai $\widehat{\boldsymbol{\beta}}_{(\mathrm{o})}^{*}$ ke dalam elemen-elemen vektor $\mathbf{g}$ dan matriks $\mathbf{H}$ sehingga diperoleh vektor $\boldsymbol{g}_{(\mathrm{o})}$ dan $\mathbf{H}_{(\mathrm{o})}$.

5. Melakukan iterasi mulai dari $\mathrm{t}=0$ pada persamaan: $\boldsymbol{\beta}_{(\mathrm{t}+1)}^{8}=\boldsymbol{\beta}_{\mathrm{t}}^{8}-\mathbf{H}_{\mathrm{t}}^{-1} \boldsymbol{g}_{\mathrm{t}}^{f}$, nilai $\boldsymbol{\beta}_{\mathrm{t}}^{8}$ merupakan sekumpulan penduga parameter yang konvergen pada iterasi ke-t.

6. Jika belum mencapai penduga parameter yang konvergen, maka pada langkah ke-2 dilakukan kembali sampai mencapai kekonvergenan. Kriteria konvergen diperoleh ketika akar ciri dari matriks informasi Fisher bernilai positif.

Uji Wald digunakan untuk menguji signifikansi dari koefisien korelasi spasial $\hat{\rho}$ dan $\widehat{\boldsymbol{\beta}}$ (Lambert et al. 2010). Pengujian hipotesis untuk $\rho$ adalah,

$H_{0}: \rho=0$ (tidak ada korelasi spasial)

$\mathrm{H}_{1}: \rho \neq 0$ (ada korelasi spasial)

$$
G_{p}=\left\{\frac{\hat{\rho}_{0}}{\hat{\operatorname{se}}\left(\hat{\rho}_{0}\right)}\right\}^{2}
$$

statistik $\mathrm{G}_{\rho}$ akan mengikuti sebaran $\chi^{2}$ dengan derajat bebas 1 . Kriteria keputusan yang diambil yaitu menolak $\mathrm{H}_{0}$, jika $\mathrm{G}_{\mathrm{p}}>\chi_{(\alpha / 2 ; 1)}^{2}$.

Hipotesis untuk parameter koefisien $\beta_{\mathrm{k}}$ (Fleiss et al. 2003) adalah,

$$
\begin{aligned}
& \mathrm{H}_{0}: \beta_{\mathrm{k}}=0 \\
& \mathrm{H}_{1}: \beta_{\mathrm{k}} \neq 0
\end{aligned}
$$

Dengan statistik uji Wald.

$$
\mathrm{G}_{\beta}=\left\{\frac{\widehat{\beta}_{\mathrm{k}}}{\hat{\mathrm{se}}\left(\widehat{\beta}_{\mathrm{k}}\right)}\right\}^{2}
$$

Statistik $\mathrm{G}_{\beta}$ akan mengikuti sebaran $\chi^{2}$ dengan derajat bebas 1 . Kriteria keputusan yang diambil

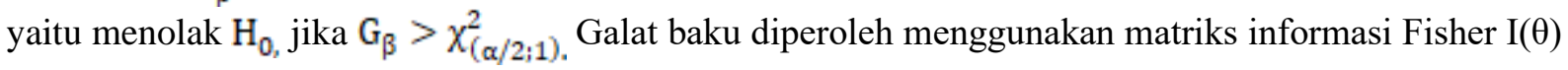
(McCulloch dan Searle, 2001), dengan rumus sebagai berikut. 


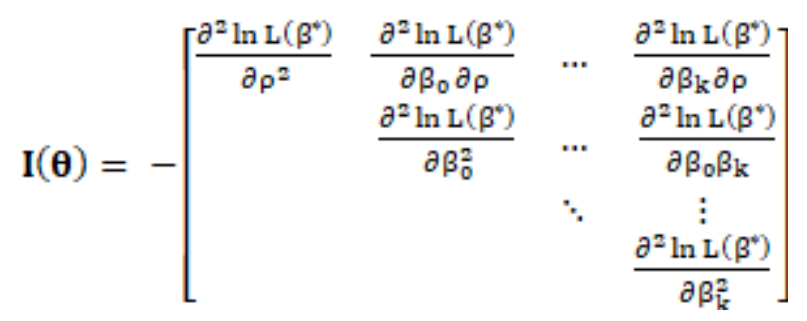

ragam dari $\widehat{\theta} \approx[\mathbf{I}(\boldsymbol{\theta})]^{-1}$, sehingga galat baku $=\sqrt{[\mathbf{I}(\boldsymbol{\theta})]^{-1}}$.

Setelah dilakukan penaksiran parameter dan uji signifikansi setiap penduga parameter, diperlukan ukuran koefisien determinasi yang dapat menggambarkan hubungan keeratan antara peubah respon dengan peubah penjelas. Koefisien determinasi atau R2 merupakan ukuran proporsi keragaman peubah respon yang dapat diterangkan oleh peubah penjelas. Salah satu R2 yang telah dikembangkan oleh (Cameron dan Windmeijer, 1995) yang didasarkan pada sisaan devians $\left(\mathrm{R}_{\mathrm{nFV}}^{2}\right)$.

Rumus untuk $\mathrm{R}_{\mathrm{DFV}}^{2}: \mathrm{R}_{\mathrm{DEV}}^{2}=1-\frac{\ln \mathrm{L}(\mathrm{y})-\ln \mathrm{L}(\tilde{\mu})}{\ln \mathrm{L}(\mathrm{y})-\ln \mathrm{L}(\overline{\mathrm{y}})}$

dengan $\ln \mathrm{L}(\mathrm{y})=\sum_{\mathrm{i}}^{\mathrm{n}}\left[\mathrm{y}_{\mathrm{i}} \ln \left(\mathrm{y}_{\mathrm{i}}\right)-\mathrm{y}_{\mathrm{i}}-\ln \left(\mathrm{y}_{\mathrm{i}} \mathrm{D}\right)\right]$ adalah logaritma bilangan asli (ln) dari fungsi kemungkinan maksimum ketika semua parameter $\beta_{\mathrm{j}}(\mathrm{j}=0,1,2, \ldots, \mathrm{k})$ tidak disertakan dalam model, $y_{\hat{\mathrm{i}}}$ adalah nilai pengamatan dari peubah respon; $\ln \mathrm{L}(\hat{\mathrm{\mu}})=\sum_{\mathrm{i}}^{\mathrm{n}}\left[\mathrm{y}_{\mathrm{i}} \ln (\hat{\mathrm{\mu}})-\hat{\mu}_{\mathrm{i}}-\ln \left(\mathrm{y}_{\mathrm{i}} \mathrm{D}\right)\right]$ adalah logaritma bilangan asli dari fungsi kemungkinan maksimum ketika semua parameter $\beta_{j}$ disertakan dalam model, $\hat{\mathrm{H}}_{\mathrm{i}}$ adalah nilai dugaan untuk pengamatan ke-i; $\ln \mathrm{L}(\overline{\mathrm{y}})=\sum_{\mathrm{i}}^{\mathrm{n}}\left[\mathrm{y}_{\mathrm{i}} \ln (\overline{\mathrm{y}})-\overline{\mathrm{y}}-\ln \left(\mathrm{y}_{\mathrm{i}} \mathrm{D}\right)\right]$ adalah logaritma bilangan asli dari fungsi kemungkinan maksimum ketika hanya $\boldsymbol{\beta}_{0}$ yang disertakan dalam model, dan $(\bar{y})$ rata-rata respon $\boldsymbol{y}$.

\section{METODE PENELITIAN}

\section{Tahapan Penelitian}

Tahapan analisis data yang dilakukan adalah sebagai berikut:

1. Menentukan peubah penjelas.

2. Menentukan statistika deskriptif untuk tiap peubah.

3. Menentukan matriks pembobot spasial $\boldsymbol{W}^{*}$.

4. Menduga parameter $\boldsymbol{\beta}$, pdengan metode Newton-Raphson.

5. Menguji signifikansi parameter dengan menggunakan uji Wald.

6. Menguji kebaikan model dengan menghitung koefisien determinansi $\left(\mathrm{R}^{2}\right)$ berdasarkan devians $\mathrm{R}_{\mathrm{nFV}}^{2}$ dan $\mathrm{R}^{2}$ adjusted.

7. Menarik Kesimpulan

Analisis dilakukan dengan menggunakan software R.2.10.1.

\section{Peubah Penelitian dan Waktu Penelitian}

Data yang digunakan dalam penelitian ini merupakan data sekunder yang berasal dari data laporan HIV/AIDS Kementerian Kesehatan dan BPS DKI Jakarta dalam angka pada tahun 2018. Peubah respon yang digunakan adalah jumlah penderita HIV/AIDS di Jakarta Timur. Adapun peubah penjelas dalam penelitian ini adalah: laju pertumbuhan penduduk $\left(\mathrm{X}_{1}\right)$, jumlah fasilitas kesehatan $\left(X_{2}\right)$, jumlah dokter dan bidan $\left(\mathrm{X}_{3}\right)$, jumlah petugas penyuluh $\mathrm{KB}\left(\mathrm{X}_{4}\right)$, jumlah rumah tangga miskin $\left(\mathrm{X}_{5}\right)$, jumlah tempat ibadah $\left(\mathrm{X}_{6}\right)$, dan jumlah timbunan sampah $\left(\mathrm{X}_{7}\right)$. 


\section{HASIL PENELITIAN}

\section{Deskripsi Tiap Peubah}

Hal pertama yang dilakukan dalam penelitian yaitu melakukan analisis deskriptif dari peubah yang digunakan. Peubah respon yang digunakan adalah jumlah penderita HIV/AIDS di Jakarta Timur. Adapun peubah penjelas dalam penelitian ini adalah: laju pertumbuhan penduduk $\left(\mathrm{X}_{1}\right)$, jumlah fasilitas kesehatan $\left(X_{2}\right)$, jumlah dokter dan bidan $\left(\mathrm{X}_{3}\right)$, jumlah petugas penyuluh $\mathrm{KB}\left(\mathrm{X}_{4}\right)$, jumlah rumah tangga miskin $\left(\mathrm{X}_{5}\right)$, jumlah tempat ibadah $\left(\mathrm{X}_{6}\right)$, dan jumlah timbunan sampah $\left(\mathrm{X}_{7}\right)$.

Tabel 1. Tabel nilai rataan dan simpangan baku untuk setiap peubah.

\begin{tabular}{crr}
\hline Peubah & Nilai Rataan & \multicolumn{1}{c}{ Simpangan Baku } \\
\hline $\mathrm{Y}$ & 102.7000 & 95.28093 \\
$\mathrm{X}_{1}$ & 89.9000 & 84.24099 \\
$\mathrm{X}_{2}$ & 17.0000 & 8.32666 \\
$\mathrm{X}_{3}$ & 118.7000 & 27.20315 \\
$\mathrm{X}_{4}$ & 6.7000 & 1.15950 \\
$\mathrm{X}_{5}$ & 5142.7000 & 2842.91283 \\
$\mathrm{X}_{6}$ & 317.3000 & 93.52843 \\
$\mathrm{X}_{7}$ & 20300.7000 & 6921.09786 \\
\hline
\end{tabular}

Berdasarkan tabel tersebut diperoleh nilai rata-rata jumlah penderita HIV/AIDS (Y) memiliki nilai rata-rata $=102.7$ lebih tinggi daripada nilai varians $=9078,278$, sehingga terjadi overdispersi .

\section{Uji Multikolinieritas}

Uji Multikolinieritas diperlukan untuk mengetahui ada tidaknya peubah independen yang lain dalam satu model. Pengujian multikolinieritas menggunakan nilai VIF dengan nilai nilai VIF > 10 maka dikatakan mengalami multikolinieritas. Uji hipotesisnya adalah sebagai berikut.

i. Hipotesis

$\mathrm{H}_{0}$ : Tidak terdapat hubungan antar peubah independen

$\mathrm{H}_{1}$ : Terdapat hubungan antar peubah independen

ii. Tingkat Signifikansi $a=0,05$

iii. Daerah Kritis Tolak $\mathrm{H}_{0}$ jika nilai VIF $>10$ dan nilai tolerance $<0,1$

iv. Keputusan

\begin{tabular}{crr}
\multicolumn{3}{c}{ Tabel 2. Tabel nilai tolerance dan nilai VIF } \\
\hline Peubah & Tolerance & \multicolumn{1}{c}{ VIF } \\
\hline X1 &, 194 & 5,153 \\
X2 &, 230 & 4,348 \\
X3 &, 299 & 3,348 \\
X4 &, 574 & 1,742 \\
X5 &, 201 & 4,974 \\
X6 &, 063 & 15,914 \\
X7 &, 043 & 23,070 \\
\hline
\end{tabular}

Berdasarkan hasil uji multikolinearitas diperoleh peubah jumlah tempat ibadah $\left(X_{6}\right)$ dan jumlah timbunan sampah $\left(X_{7}\right)$ terjadi multikolinearitas. Hal ini dilihat dari nilai VIF berturut-turut untuk kedua peubah tersebut sebesar $=15.914$ dan 23.070 yang keduanya lebih dari 10. Selain itu, peubah penjelas laju pertumbuhan penduduk $\left(X_{1}\right)$, jumlah fasilitas kesehatan $\left(X_{2}\right)$, jumlah dokter dan bidan $\left(X_{3}\right)$, jumlah petugas penyuluh $\mathrm{KB}\left(X_{4}\right)$, jumlah rumah tangga miskin $\left(X_{5}\right)$, sehingga layak diikutsertakan dalam pembentukan model regresi Poisson maupun model SAR Poisson. Hal ini dapat dilihat dari nilai VIF yang kurang dari 10 dan nilai tolerance yang lebih dari 0,1 . 


\section{Analisis Model Regresi Poisson}

Pendugaan parameter diperoleh menggunakan perangkat lunak R. Hasil pendugaan parameter untuk model regresi Poisson dapat dilihat pada tabel berikut.

Tabel 3. Nilai dugaan parameter model regresi Poisson

\begin{tabular}{crrrr}
\hline Peubah & Nilai dugaan & Galat baku & \multicolumn{1}{c}{ Nilai G } & $\boldsymbol{\chi}_{\mathbf{1}}^{\mathbf{2}}$ \\
\hline Intersep & $6,25 \mathrm{e}+00$ & $2,25 \mathrm{e}-01$ & $7,72 \mathrm{E}+02^{*}$ & \\
$\mathrm{X}_{1}$ & $4,406 \mathrm{e}-01$ & $8,004 \mathrm{e}-02$ & $3,03 \mathrm{E}+01^{*}$ & \\
$\mathrm{X}_{2}$ & $7,43 \mathrm{e}-02$ & $5,912 \mathrm{e}-03$ & $1,58 \mathrm{E}+02^{*}$ & 3.841 \\
$\mathrm{X}_{3}$ & $-2,063 \mathrm{e}-02$ & $2,093 \mathrm{e}-03$ & $9,72 \mathrm{E}+01^{*}$ & \\
$\mathrm{X}_{4}$ & $-1,576 \mathrm{e}-01$ & $4,109 \mathrm{e}-02$ & $1,47 \mathrm{E}+01^{*}$ & \\
$\mathrm{X}_{5}$ & $1,188 \mathrm{e}-05$ & $2,568 \mathrm{e}-05$ & $2,14 \mathrm{E}-01^{\mathrm{TN}}$ & \\
\hline
\end{tabular}

Keterangan: * nyata pada taraf alpha $5 \%$

Analisis model regresi Poisson di Kota Jakarta Timur, pada Tabel 3 menunjukkan uji signifikansi setiap penduga parameter menggunakan Uji Wald. Hasil uji Wald pada taraf $\alpha=5 \%$ memperlihatkan bahwa $X_{1}, X_{2}, X_{3}, X_{4}$ yang dimasukkan dalam model adalah signifikan, sedangkan peubah $X_{5}$ tidak signifikan. Tabel 2 menunjukkan bahwa semakin rendah $X_{3}$ dan $X_{4}$ akan meningkatkan jumlah penderita HIV/AIDS. Berbeda dengan peningkatan $X_{1}, X_{2}$, dan $X_{5}$ akan meningkatkan jumlah penderita HIV/AIDS.

Model tersebut menunjukkan bahwa setiap penambahan satu satuan laju pertumbuhan penduduk di suatu kecamatan akan menyebabkan nilai harapan penderita HIV/AIDS meningkat sebesar $\exp (0.4406)=1,5536$ kali dengan asumsi peubah lain dianggap tetap. Artinya, setiap terjadi penambahan 10000 penduduk maka nilai harapan penderita HIV/AIDS juga akan meningkat sebanyak 15536 orang dengan asumsi peubah lain dianggap tetap. Selain itu, uji kebaikan modelnya diperoleh $\mathrm{R}^{2}$ devians sebesar 0.4947 dan $\mathrm{R}^{2}$ adjusted $=0.4883$.

Adapun hasil nilai dugaan miu model regresi Poisson $(\mu)$ adalah sebagai berikut:

\begin{tabular}{c} 
Tabel 4. Hasil Nilai Dugaan Miu Model Regresi Poisson \\
\hline Nilai dugaan Dugaan Miu Model Regresi Poisson \\
\hline 104,00683 \\
174,54257 \\
62,38591 \\
67,25068 \\
83,97422 \\
41,88045 \\
80,75679 \\
37,65843 \\
244,36113 \\
130,18299 \\
\hline
\end{tabular}

Analisis Model Autoregresif Spasial Poisson

Berdasarkan hukum Tobler bahwa segala sesuatu saling berhubungan satu dengan yang lainnya, tetapi sesuatu yang dekat lebih mempunyai pengaruh daripada sesuatu yang jauh. Pada penelitian ini jumlah penderita HIV/AIDS dapat diasumsikan menyebar Poisson dan untuk melihat pengaruh spasial antar lokasi di setiap kecamatan di Jakarta Timur maka analisis yang digunakan adalah spasial otoregresif poisson.

Pendugaan parameter koefisien model spasial otoregresif Poisson (SAR Poisson) dilakukan dengan menggunakan metode pendugaan kemungkinan maksimum. Model SAR Poisson termasuk model nonlinear dan bentuknya tidak closed form, sehingga proses pendugaan parameter koefisien regresinya menggunakan iterasi dengan metode Newton-Raphson. 
Tabel 5. Nilai dugaan parameter model spasial otoregresif Poisson

\begin{tabular}{crrrr}
\hline Peubah & Nilai dugaan & Galat baku & Nilai G & $\boldsymbol{\chi}_{\mathbf{1}}^{\mathbf{2}}$ \\
\hline Korelasi spasial & $-0,47266933$ & 0,023704423 & $397,6089^{*}$ & \\
Intersep & 625,493175 & 0,000230654 & $7,35 \mathrm{E}+12^{*}$ & \\
X1 & 0,44054182 & $1,96261 \mathrm{E}-06$ & $5,04 \mathrm{E}+10^{*}$ & \\
X2 & 0,07311958 & $3,94493 \mathrm{E}-05$ & $3435482^{*}$ & 3.841 \\
X3 & $-0,02866532$ & 0,000268809 & $11371,74^{*}$ & \\
X4 & $-0,50691594$ & 0,011834085 & $1834,858^{*}$ & \\
X5 & $-0,02154856$ & 0,000727037 & $878,4622^{*}$ & \\
\hline
\end{tabular}

Keterangan: *: nyata pada taraf alpha $5 \%$

Analisis model SAR Poisson di Kota Jakarta Timur dengan melibatkan seluruh wilayah kecamatan memperlihatkan bahwa jumlah penderita HIV/AIDS dipengaruhi oleh kedekatan wilayah dan semua peubah penjelas yang signifikan. Pada Tabel 3 menunjukkan uji signifikansi setiap penduga parameter menggunakan Uji Wald. Hasil uji Wald memperlihatkan bahwa nilai korelasi spasial signifikan. Hasilnya diperoleh nilai korelasi spasial $=-0,47$ dengan nilai $\mathrm{G}_{\rho}=397,6089$, dan nilai $\chi_{1}^{2}=3.841$. Hal ini menunjukkan korelasi spasial pada model nyata pada taraf $\alpha=5 \%$. Dengan demikian dapat disimpulkan bahwa lokasi-lokasi yang berdekatan mempunyai nilai yang berbeda dan cenderung menyebar. Uji signifikansi untuk setiap penduga parameter diperoleh nilai $\mathrm{G}_{\beta}>\chi_{1}^{2}$. Hal ini menunjukkan bahwa $\mathrm{X}_{1}, \mathrm{X}_{2}, \mathrm{X}_{3}, \mathrm{X}_{4}$, dan $\mathrm{X}_{5}$ yang dimasukkan dalam model adalah signifikan. Tabel 5 menunjukkan bahwa semakin rendah $\mathrm{X}_{3}, \mathrm{X}_{4}, \mathrm{X}_{5}$ akan meningkatkan jumlah penderita HIV/AIDS. Berbeda dengan peningkatan $\mathrm{X}_{1}$ dan $\mathrm{X}_{2}$ akan meningkatkan jumlah penderita HIV/AIDS.

Berdasarkan model yang diperoleh menunjukkan bahwa setiap peningkatan satu satuan laju pertumbuhan penduduk di suatu kecamatan akan menyebabkan nilai harapan penderita HIV/AIDS meningkat sebesar $\exp (0.4406)=1,5536$ kali dengan asumsi peubah lain dianggap tetap. Artinya, setiap terjadi penambahan 10000 penduduk maka nilai harapan penderita HIV/AIDS juga akan meningkat sebanyak 15536 orang dengan asumsi peubah lain dianggap tetap.

\section{KESIMPULAN DAN SARAN}

\section{Kesimpulan}

1) Faktor-faktor yang mempengaruhi jumlah penderita HIV/AIDS di Kota Jakarta Timur adalah faktor spasial dan nonspasial.

2) Faktor spasialnya yang mempengaruhi untuk lokasi tertentu adalah lokasi pada tetangganya. Berdasarkan model SAR Poisson diperoleh korelasi spasial yang signifikan sebesar $\rho=-0,47$. Hal ini berarti bahwa lokasi-lokasi yang berdekatan mempunyai nilai yang berbeda dan cenderung menyebar.

\section{Saran}

1) Berdasarkan kesimpulan di atas diketahui bahwa faktor spasial memiliki pengaruh yang signifikan. Oleh karena itu, untuk menyelesaikan kasus HIV/AIDS pada tiap kecamatan di Jakarta Timur penting untuk memperhatikan kedekatan antar lokasi.

2) Penggunaan metode Newton-Raphson untuk menduga parameter sensitif terhadap nilai awal sehingga perlu dicari metode lagi yang lebih efisien untuk menduga parameternya.

3) Pada kasus untuk peubah responnya terjadi overdispersi. Oleh karena itu, sangat penting dicari upaya untuk mengatasi permasalahan tersebut.

\section{UCAPAN TERIMA KASIH}

Terima kasih kepada BLU FMIPA UNJ yang telah mendukung penelitian ini. 


\section{REFERENSI}

Anselin, L. (1988) Spatial Economics: Methods and Models. Dordrecht: Kluwer Academic Publishers.

DKI Jakarta. Badan Pusat Statistika (2013) Provinsi DKI Jakarta dalam Angka. Jakarta: BPS DKI Jakarta.

Fotheringham, A.S. and Rogerson, P.A. (2009) The SAGE handbook of spatial analysis. London: Sage Publications Ltd.

Haran, M., Molineros, J. and Patil, G.P. (2006) 'Large scale plant disease forecasting: Case study of Fusarium Head Blight', Center for Statistical Ecology and Environmental Statistics, p.9.

Kulldorff, M. (1997) 'A spatial scan statistic'. Communications in Statistics-Theory and methods, 26(6), pp.1481-1496 [online]. Available at: http://www.satscan.org/papers/kcstm1997.pdf (Accessed: 27 Juli 2011)

Lambert, D.M., Brown, J.P. and Florax, R.J. (2010) 'A two-step estimator for a spatial lag model of counts: Theory, small sample performance and an application', Regional Science and Urban Economics, 40(4), pp.241-252.

Lee, J. and Wong, D.W.S. (2001) Statistic for Spatial Data. New York: John Wiley \& Sons. Inc.

Ratnasari, N.T. and Purhadi, P. (2013) 'Pemodelan Faktor yang Mempengaruhi Jumlah HIV dan AIDS Provinsi Jawa Timur Menggunakan Regresi Poisson Bivariat', Jurnal Sains dan Seni ITS, 2(2), pp.D213-D218.

Republik Indonesia. Ditjen P2P Kemenkes. (2017) Laporan Situasi Perkembangan HIV-AIDS \& PIMS di Indonesia. Jakarta: Ditjen P2P Kemenkes RI , pp.2-21.

Sari AW, et al. (2014) Estimasi dan Proyeksi HIV/ AIDS di Indonesia Tahun 2011-2016. [Kementerian Kesehatan Republik Indonesia]

Simanjuntak, S. and Purhadi, P. (2017) 'Pemodelan Jumlah Kasus HIV dan AIDS di Kota Surabaya Menggunakan Bivariate Generalized Poisson Regression', Jurnal Sains dan Seni ITS, 6(2), pp.D198-D203.

Wuryandari, T., Hoyyi, A., Kusumawardani, D.S. and Rahmawati, D. (2014) 'Identifikasi Autokorelasi Spasial Pada Jumlahpengangguran Di Jawa Tengah Menggunakan Indeks Moran', Media Statistika, 7(1), pp.1-10. 